\title{
Explanation of the Viewpoint of Dental Students Towards the Study Guide of the Oral Medicine Course
}

\author{
Shirazian sh ${ }^{1}$, Mansourian $\mathbf{A}^{2}$, Vatanpour $\mathbf{M}^{3^{*}}$, Ghasemi $\mathbf{N}^{4}$ \\ ${ }^{1}$ Assisstant professor, Oral Medicine,faculty of dentistry Dept, Tehran University of Medical Sciences \\ ${ }^{2}$ Associate professor, Oral Medicine, faculty of dentistry Dept, Tehran University of Medical Sciences \\ ${ }^{3}$ Assistant professor, Endodontics Dept,Dental Branch of Tehran, Islamic Azad University, Tehran, Iran \\ ${ }^{4}$ Dentist
}

\begin{tabular}{l}
\hline ARTICLE INFO \\
\hline Article Type \\
Original Article \\
Article History \\
Received: Jan 2017 \\
Accepted: Feb 2017 \\
ePublished: Apr 2017 \\
\hline
\end{tabular}

Keywords:

Study guide,

Satisfaction,

Dental student

\section{ABSTRACT}

Background and aim: Study guide is a tool for establishing the student-centered learning process. It is an assortment for directing the student in the management of his learning by foreseeing educational obligations, aims and contents. Considering the important role of study guides in students' learning process, the aim of the present study was to explain the point of view of dental students towards the study guide of the oral medicine course.

Materials and methods: This study was performed in two phases: 1-compilation of a study guide for the practical oral medicine course, and 2- implementation of the study guide by 73 dental students, evaluation of their point of view towards its items, and also estimation of their level of satisfaction.

Results: $48.6 \%$ of the participants were completely satisfied, $18.1 \%$ were moderately satisfied; whereas, $6.9 \%$ were unsatisfied with the study guide. $26.4 \%$ of the students had left the open questions unanswered. $71.2 \%$ of the students needed some examples for implementing theoretical lessons in the clinical setting. Few students felt the need to know about the role of the department's personnel.

Conclusion: A high percentage of the students were moderately or completely satisfied with the study guide. They believed that the study guide has improved their learning process, and has even resulted in higher final scores. Knowing the opinion of students is useful for revision and improvement of the study guide.

\footnotetext{
Please cite this paper as: Shirazian S, Mansourian A, Vatanpour M, Ghasemi N. Explanation of the Viewpoint of Dental Students Towards the Study Guide of the Oral Medicine Course. J Res Dent Maxillofac Sci. 2017;2(2):34-43.
} 


\section{Introduction:}

Study guide is a tool that facilitates student's interaction with different parts of the curriculum. ${ }^{(1)}$ Harden et al have defined the study guide as "a guide, usually in the format of printed scripts, which is designed to help the learners in their learning process, and shows what must be learned, how it can be learned, and how the learners can recognize that whether or not they have learned the subject". Study guide is one of the most effective and important tools in improving the quality of education. ${ }^{(2)}$ Occasionally, the study guide is confused with reference books, despite the distinct differences between the two. Reference book is a collection of information with emphasis on their content; however, study guide:

1. Tells the student how to earn the necessary proficiency in accomplishment of duties such as performing health role in treating the disease.

2. Defines the start point of learning that the student builds based on his experiences.

3. Depicts a wide range of activities that can lead to constant and stable learning.

4. Clearly declares the range of learning objectives, especially those related to proficiency and attitude. Study guide is a tool designed to facilitate student's interaction with different parts of the curriculum. This educational tool helps students to design their learning with regards to the expected results, take the best advantage of learning opportunities, detect suitable learning strategies, get prepared for evaluation methods, and properly react in the institution's learning environment. With the help of the study guide, it can be realized that: A) What must be learned (content), B) How it must be learned (learning management), C) How it can be recognized that whether the education has led to learning (performed learning activities). ${ }^{(3)}$

The use of study guide has been compared to a teacher that sits shoulder to shoulder with the student, and remarks some explanations related to what must be performed in each step in all 24 hours. ${ }^{(3)}$

Study guide has three roles in improved learning: 1) facilitating learning by students, 2) orienting students' activities towards learning, 3) providing the information related to the important topics. $^{(4)}$

Study guide provides the prerequisites that are necessary for students to know before learning; (4) therefore, it is a key and fundamental tool in learning process. Attention to the following six categories in education, further clarifies the importance of the use of study guide in medical education: ${ }^{(5)}$

1. Increased potential data volume, 2. Changes in the curriculum, 3. Spiral curriculum, 4. Independent learning, 5. Work-based learning, 6. Remote learning

The amount of time allocated to study guide preparation is extremely important. Students will benefit from a study guide that has been properly designed. On the other hand, no student is willing to read an unattractive study guide with a poor design. ${ }^{(6)}$ In fact, students will use the study guide only if this guide is beneficial and brief at the same time and can satisfy their needs and direct them in educational fields.

Since in the informationera, education is shifting from teacher-centered to student-centered method, ${ }^{(7)}$ and study guide is one of the tools of this educational template, and also by considering the importance of the study guide's contents, in the present study we designed and implemented an oral medicine study guide for semester eight dental students of Tehran University of Medical Sciences, and afterwards, we evaluated the viewpoints of the students towards the study guide and assessed their degree of satisfaction.

\section{Materials and methods}

This study has been performed in two stages; first stage: compilation of a study guide, and second stage: implementation of the study guide by students, and evaluation of their viewpoints and their degree of satisfaction.

Compilation of the study guide:

Compiling the study guide included the following stages:

A) Deciding the enactment and design of the study guide:

In this stage, we determined the topic of the study guide. The purpose of writing and the de- 
sign and manner of publication of the study guide were determined with the aid of valid references and methods.

B) Adaptation of the study guide with the curriculum:

In this stage, the study guide was adapted with the curriculum, and all the required materials for effective learning in the oral medicine department were gathered. The needed references were obtained and gathered, and the learning strategies were determined. Afterwards, the predicted contents were handed to all the oral medicine faculty members, and they wrote their opinions and recommendations. For example, one of the aims of the practical oral medicine 1 course is to learn the principles of head and neck examination. In this regard, the educational contents related to this topic were gathered and after adaptation with the curriculum, they were handed to the faculty members for assessment in order to select the proper educational method between watching an educational video or demonstration on a patient in the clinic.

C) Writing the study guide

In this stage, the suggested comments of all the oral medicine faculty members with regards to adding the proposed content were applied, and the final compiled study guide was again handed to the faculty members, and after their approval, this guide was handed on arrival to all the semester eight dental students taking the practical oral medicine 2 course.

Second stage: after initial compilation of the study guide, its contents were approved by all the five members of the oral medicine faculty including: the head of the department, educational assistant, specialist supervisor and two group members, and the study guide was handed to the students.

At the end of the semester, the viewpoints of the students towards the study guide and their degree of satisfaction were assessed by using a questionnaire.

Statistical analysis:

After collecting the data, the obtained information was presented in the related tables and graphs with the aid of descriptive statistics.

\section{Results}

73 students with the average age of $22 \pm 1$ years ( 21 to 23 years old), including 41 females and 32 males, participated in the present study. The answers of the students to each of the items in the questionnaire are presented in Table 1. 
Table 1- Answers of the students to each of the items in the questionnaire

\begin{tabular}{|c|c|c|c|c|c|c|c|c|}
\hline \multirow{2}{*}{\multicolumn{2}{|c|}{$\begin{array}{l}\text { Items in the study guide } \\
\text { Learning management }\end{array}$}} & \multicolumn{3}{|c|}{$\begin{array}{l}\text { Level of student's familiarity with the item } \\
\text { (before reading the study guide) }\end{array}$} & \multicolumn{4}{|c|}{ Feeling the need for the item after reading the study guide } \\
\hline & & None & Incomplete & Complete & Low & Moderate & \multicolumn{2}{|c|}{ High } \\
\hline 1 & Syllabuses & $20.29 \%$ & $57.97 \%$ & $21.74 \%$ & $7.7 \%$ & $32.3 \%$ & \multicolumn{2}{|c|}{$60 \%$} \\
\hline 2 & $\begin{array}{l}\text { Learning objectives of } \\
\text { courses }\end{array}$ & $20 \%$ & $58.6 \%$ & $21.4 \%$ & $11.1 \%$ & $39.7 \%$ & \multicolumn{2}{|c|}{$49.2 \%$} \\
\hline 3 & Prerequisite course & $17.4 \%$ & $58 \%$ & $24.6 \%$ & $18.2 \%$ & $40.9 \%$ & \multicolumn{2}{|c|}{$40.9 \%$} \\
\hline 4 & $\begin{array}{c}\text { Lesson presentation } \\
\text { schedule }\end{array}$ & $31.3 \%$ & $49.3 \%$ & $19.4 \%$ & $16.4 \%$ & $26.9 \%$ & \multicolumn{2}{|c|}{$56.7 \%$} \\
\hline 5 & Learning opportunity & $25 \%$ & $55.9 \%$ & $19 \%$ & $9.1 \%$ & $33.3 \%$ & \multicolumn{2}{|c|}{$57.6 \%$} \\
\hline & \multicolumn{2}{|c|}{ Items in the study guide } & \multicolumn{3}{|c|}{$\begin{array}{l}\text { Level of student's familiarity with the item } \\
\text { (before reading the study guide) }\end{array}$} & \multicolumn{3}{|c|}{$\begin{array}{l}\text { Feeling the need for the item after } \\
\text { reading the study guide }\end{array}$} \\
\hline \multicolumn{3}{|c|}{ Assessment } & None & Incomplete & Complete & Low & Moderate & High \\
\hline 1 & \multicolumn{2}{|c|}{$\begin{array}{l}\text { Endorsements and regulations of the } \\
\text { department }\end{array}$} & $7.1 \%$ & $52.9 \%$ & $40 \%$ & $28.8 \%$ & $28.8 \%$ & $42.4 \%$ \\
\hline 2 & \multicolumn{2}{|c|}{ Describing student's duties } & $8.5 \%$ & $53.5 \%$ & $38 \%$ & $16.9 \%$ & $27.7 \%$ & $55.4 \%$ \\
\hline 3 & \multicolumn{2}{|c|}{ Student evaluation method } & $16.9 \%$ & $49.3 \%$ & $33.8 \%$ & $20.3 \%$ & $21.9 \%$ & $57.8 \%$ \\
\hline \multicolumn{3}{|c|}{ Activities } & \multicolumn{3}{|c|}{$\begin{array}{l}\text { Level of student's familiarity with the item } \\
\text { (before reading the study guide) }\end{array}$} & \multicolumn{3}{|c|}{$\begin{array}{l}\text { Feeling the need for the item after } \\
\text { reading the study guide }\end{array}$} \\
\hline 1 & \multicolumn{2}{|c|}{$\begin{array}{l}\text { offering guidance or questions for } \\
\text { better comprehending the lessons }\end{array}$} & $21.7 \%$ & $59.4 \%$ & $18.8 \%$ & $7.5 \%$ & $37.3 \%$ & $55.2 \%$ \\
\hline 2 & \multicolumn{2}{|c|}{$\begin{array}{l}\text { Offering examples for implementing } \\
\text { theoretical lessons in practice }\end{array}$} & $21.1 \%$ & $53.5 \%$ & $25.4 \%$ & $13.6 \%$ & $15.2 \%$ & $71.2 \%$ \\
\hline 3 & \multicolumn{2}{|c|}{ Self-assessment exercises } & $42.3 \%$ & $42.3 \%$ & $15.5 \%$ & $9.2 \%$ & $40 \%$ & $50.8 \%$ \\
\hline 4 & \multicolumn{2}{|c|}{$\begin{array}{l}\text { Research field available in the } \\
\text { department }\end{array}$} & $45.7 \%$ & $45.7 \%$ & $8.6 \%$ & $18.5 \%$ & $30.8 \%$ & $50.8 \%$ \\
\hline \multicolumn{3}{|c|}{ Executive management } & \multicolumn{3}{|c|}{$\begin{array}{l}\text { Level of student's familiarity with the item } \\
\text { (before reading the study guide) }\end{array}$} & \multicolumn{3}{|c|}{$\begin{array}{l}\text { Feeling the need for the item after } \\
\text { reading the study guide }\end{array}$} \\
\hline 1 & \multicolumn{2}{|c|}{$\begin{array}{r}\text { The faculty member's executive } \\
\text { responsibility }\end{array}$} & $22.9 \%$ & $52.9 \%$ & $24.3 \%$ & $9.8 \%$ & $41.10 \%$ & $49.2 \%$ \\
\hline 2 & \multicolumn{2}{|c|}{ Teachers responsible for each lesson } & $20 \%$ & $44.3 \%$ & $35.7 \%$ & $11.1 \%$ & $28.6 \%$ & $60.3 \%$ \\
\hline 3 & \multicolumn{2}{|c|}{ Personnel and their duties } & $13.2 \%$ & $57.4 \%$ & $29.4 \%$ & $16.4 \%$ & $52.5 \%$ & $31.1 \%$ \\
\hline 4 & \multicolumn{2}{|c|}{$\begin{array}{r}\text { Time and place of access to faculty } \\
\text { members }\end{array}$} & $14.3 \%$ & $58.6 \%$ & $27.1 \%$ & $13.8 \%$ & $33.8 \%$ & $52.3 \%$ \\
\hline 5 & \multicolumn{2}{|c|}{$\begin{array}{r}\text { Location of classes and group } \\
\text { seminars }\end{array}$} & $13 \%$ & $44.9 \%$ & $42 \%$ & $15.2 \%$ & $35.9 \%$ & $51.6 \%$ \\
\hline 6 & \multicolumn{2}{|c|}{ Group laboratories } & $52.2 \%$ & $34.3 \%$ & $13.4 \%$ & $19 \%$ & $39.7 \%$ & $41.3 \%$ \\
\hline
\end{tabular}


Among the items of the study guide, the students mostly felt the need for some examples for implementing theoretical courses in practice; whereas, information about the personnel and their duties was among the least needed items. (Figure 1)

Table 2- Impact rate of the study guide in each of the educational areas from the students> perspective

\begin{tabular}{lccc}
\hline & $\begin{array}{c}\text { Completely } \\
\text { favorable }\end{array}$ & $\begin{array}{c}\text { Moderately } \\
\text { favorable }\end{array}$ & Unfavorable \\
\hline Learning & $\% 22.7$ & $\% 72.7$ & $\% 4.5$ \\
\hline $\begin{array}{l}\text { Achieving } \\
\text { educational goals }\end{array}$ & $\% 30$ & $\% 61.4$ & $\% 8.6$ \\
\hline $\begin{array}{l}\text { Better use of the } \\
\text { teaching time in } \\
\text { the department }\end{array}$ & $\% 38.6$ & $\% 48.6$ & $\% 12.9$ \\
\hline $\begin{array}{l}\text { Better use of the } \\
\text { time outside the } \\
\text { department for } \\
\text { learning }\end{array}$ & $\% 33.3$ & $\% 39.1$ & $\% 27.5$ \\
\hline $\begin{array}{l}\text { Motivation with } \\
\text { regards to the oral } \\
\text { medicine course }\end{array}$ & $\% 28.6$ & $\% 37.1$ & $\% 34.3$ \\
\hline $\begin{array}{l}\text { Reducing intra- } \\
\text { departmental } \\
\text { problems }\end{array}$ & $\% 31.4$ & $\% 52.9$ & $\% 15.7$ \\
\hline $\begin{array}{l}\text { Increasing the } \\
\text { final score of the } \\
\text { oral medicine } \\
\text { course }\end{array}$ & $\% 27.1$ & $\% 55.7$ & $\% 17.1$ \\
\hline
\end{tabular}

From the students' point of view, the impact of the study guide on different educational areas has been perceived to be moderately favorable. (Table 2)

The following results were obtained in response to the open questions at the end of the questionnaire:

In total, $48.6 \%$ of the students were completely satisfied with the study guide, $18.1 \%$ were moderately satisfied; whereas, $6.9 \%$ were unsatisfied. Albeit, $26.4 \%$ of the students had left these questions unanswered. Moreover, $45 \%$ of the students that had answered the open questions, declared that by using the study guide, they have become more familiar with their duties and teachers responsibilities, score distribution, the department and the educational goals of the department, and also with this course, and acknowledged these items as the strength points of the study guide. They also stated that by using the study guide, they have entered the department with a more open vision and have witnessed their own progress. $5 \%$ of the students mentioned the unjustified teachers and lack of precise introduction of references as the weak points of this study guide. From 73 students, $40.3 \%$ felt the change in all their educational aspects in comparison with the previous semester. 
Group laboratories

Personnel and their duties

The faculty member's executive responsibility

Endorsements and regulations of the...

Prerequisite course

Learning objectives of courses

Research field available in the department

Self-assessment exercises

Location of classes and group seminars

Time and place of access to faculty members

Offering guidance or questions for better...

Describing student's duties

Lesson presentation schedule

Learning opportunity

Student evaluation method

Syllabuses

Teachers responsible for each lesson

Offering examples for implementing...
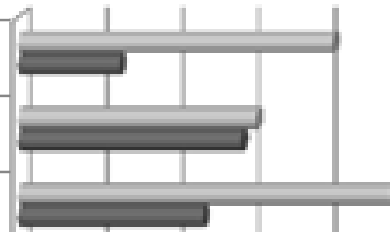

.
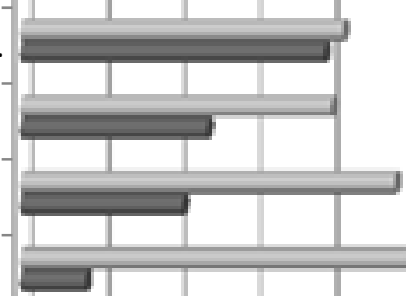

E
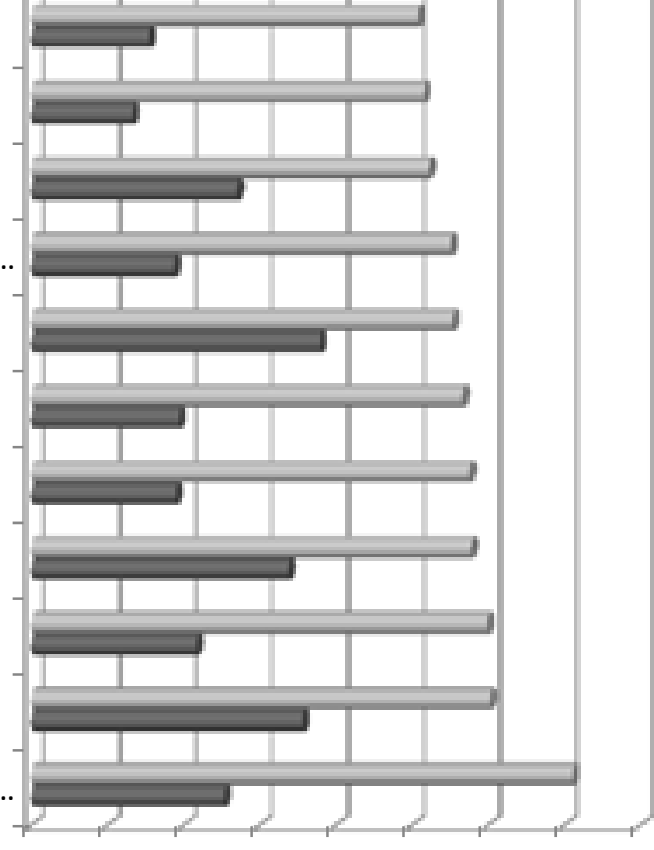

$-$

$\begin{array}{llllllllll}0 & 0 & 10 \% & 20 \% & 30 \% & 40 \% & 50 \% & 60 \% & 70 \% & 80 \%\end{array}$
Need

- Level of

familiarity

Figure 1- Level of students' need, and familiarity with the items of the study guide 
Considering the results, presence of the following items in the study guide is extremely essential and helpful for the students:

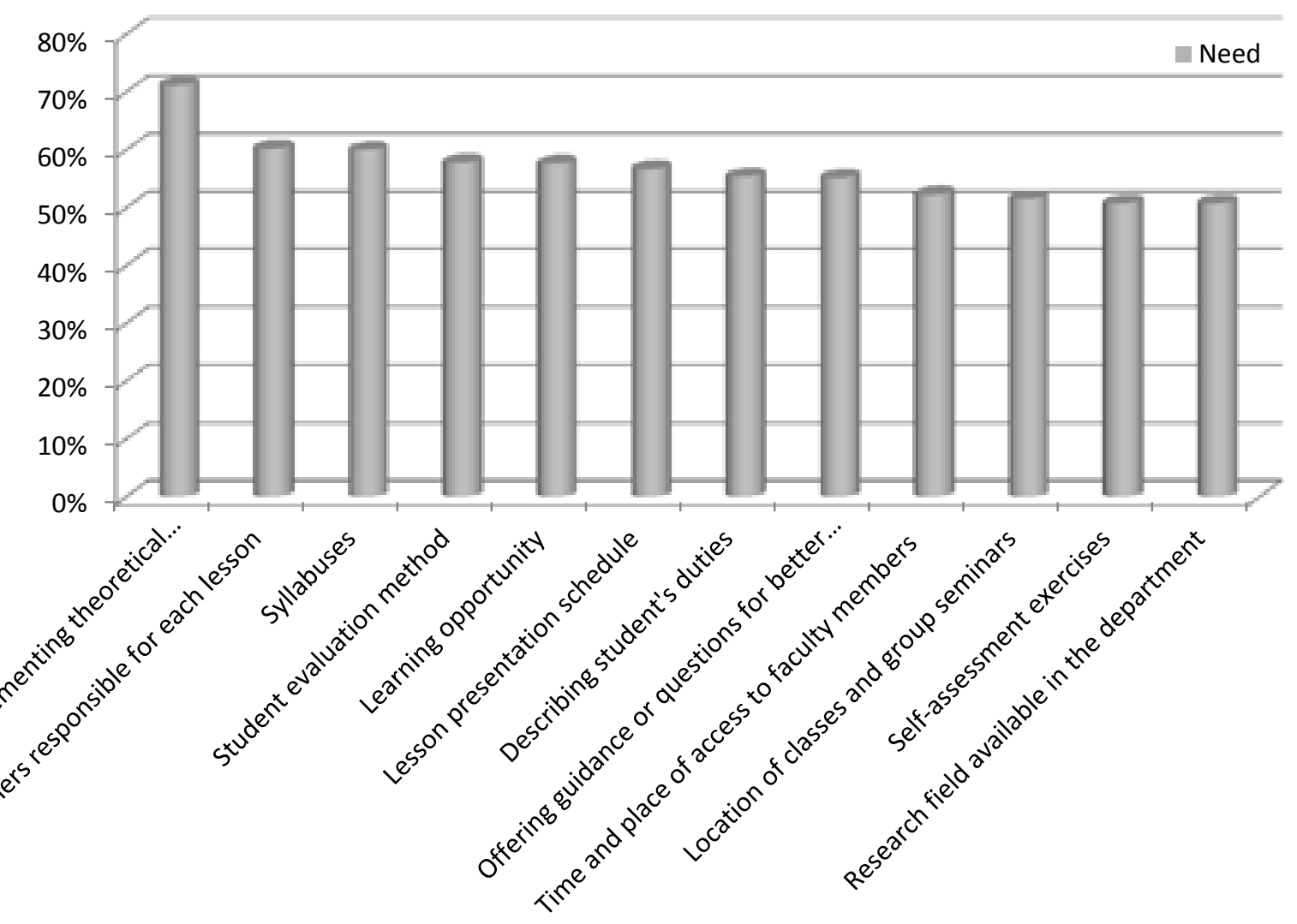

Figure 2- Most needed items in the study guide

\section{Discussion}

The purpose of the present study was to explain the viewpoint and assess the level of satisfaction of the students of the dental school of Tehran University of Medical Sciences with regards to the study guide of the oral medicine course.

The amount of time allocated to prepare the study guide is extremely important. Students can benefit from a properly designed study guide. On the other hand, no student is willing to read an unattractive study guide with a poor design. ${ }^{(6)}$ Therefore, in the present study, after the preliminary compilation, the contents of the study guide were approved by all the members of the oral medicine faculty, and the study guide was adapted with the curriculum prior to being presented to the students. The study guide can be in printed or electronic format. ${ }^{(8)}$ The printed format was used in the present study.

Holsgrove et al in 1998 reported that a properly deigned study guide can be very efficient; however, students will not try to ease the difficulty of using an unattractive study guide with a poor design. ${ }^{(9)}$ In the present research, open questions were included at the end of the questionnaire in order to improve the study guide, so that the students can write the study guide's strength and weak points and their suggestions for improving the study guide. The students' opinions can be used for future revisions to facilitate the application of the study guide.

$45 \%$ of the students that had answered the 
and have witnessed their own progress with the help of the study guide.

Holsgrove et al have also mentioned that there may be a need for separate study guides for students, teachers and institutions, so that each of them can perform their duty in establishing the process of teaching and learning. ${ }^{(9)}$ Therefore, in the present study, the study guide has been designed specifically for students. Albeit, the opinion of all the teachers in the oral medicine department with regards to the content of the study guide has been applied in order to gain their approval; however, the aim of the study guide was the group of students.

Mires et al made their study guide more attractive for the students, and encouraged them to use it by presenting items such as: 1- defined syllabuses, 2- aims of each syllabus, 3- work schedule of each student, 4articles for consolidated learning, 5- clinical duties of each student along with one structured clinical case related to the syllabus, 6assessment of each student. 94\% of the students described the study guide as extremely helpful. ${ }^{(10)}$ In the current study, $66.7 \%$ of the students were satisfied with the study guide (completely or moderately). Lower level of student satisfaction in the present study compared to the study by Mires et al can be attributed to the use of log book for registering the clinical performance of students which can further motivate them, and also further familiarize and involve them with the curriculum and their duties. Since no log book was used in the current study for registering the students' activities, they were less satisfied with the study guide in comparison with the study by mires et al.

Harden et al stated that with the help of the study guide, it can be realized that what must be learned (content), how the learning must be accomplished (learning management), and how it can be perceived that whether teaching has led to learning (performed learning activities). They presented items in their study which should be included in the study guide; however, they did not perform any surveys with regards to the items. ${ }^{(4)}$

In the current study, the opinions of the students with regards to the items in the study guide were assessed, and the results showed that presence of items: 1. Offering guidance or questions for better comprehending the lessons $(71.2 \%$ student's need) 2 . Teachers responsible for each course $(60.3 \%$ student's need) 3. Syllabuses (60\% student's need) 4 . Student evaluation method (57.8\% student's need) were highly necessary in the students' opinion, while presence of items such as prerequisite courses, and personnel and their responsibilities were not beneficial from the students' perspective. However, Harden et al stated that these items are necessary. It should be noted that this survey is important, since it can be used to further summarize the study guide, so that it becomes more attractive and beneficial for the students.

In some studies, it has been concluded that use of a clinical study guide increases the evaluation score of students, and that there have been differences between the post-evaluation scores of control and experimental groups, which had been educated using the conventional method and the study guide, respectively. The post-evaluation score of the group that had used the study guide was significantly higher than that of the control group. The sample size of the first study was equal to 24 individuals, while the sample size of the second study was equal to 45 subjects. In the present study, $82.8 \%$ of the students declared that the study guide has been effective in increasing their scores. ${ }^{(11,12)}$

Khogali et al assessed the different formats of study guide. ${ }^{(13)}$ Among three types of study guide, the timetable-based type was selected as the best format of study guide by students $(69 \%)$, while the problem-based type attracted $17 \%$ of the students, and the outcome-based type attracted $11 \%$ of the students. In the current study, the presented content was of timetable-based type. $66.7 \%$ 
of the students were moderately or completely satisfied with the study guide, $6.9 \%$ of the students were unsatisfied with the guide, while $26.4 \%$ of the students had left the open questions unanswered. In the study by Khogali et al, the benefits and different types of the study guide were judged at the same time; however, the present study only evaluated one type of study guide. Khogali and colleagues stated that the reason for less satisfaction of students with the other two types of study guide is less familiarity with these educational methods. ${ }^{(13)}$

It is important to note that these researches are still limited in Iran, and that students and teachers need more time to become more familiar with different types of study guide, so that further evaluations can be performed in this regard. Considering the obtained percentages in the present study regarding the students' attitude towards the items presented in the study guide, the current study guide must be revised, and items such as 1 . Offering guidance or questions for better comprehending the lessons 2. Teachers responsible for each lesson 3. Syllabuses 4. Student evaluation method, which showed the highest percentage of students' need, should be included in the revised study guide or should be further explained; whereas, items such as prerequisites for each course, and personnel and their duties, which will not be beneficial for the students, should be either omitted or only briefly explained, so that the study guide can be brief as well as most beneficial for the students.

\section{Conclusions:}

In the present study, a high percentage of the students were moderately or completely satisfied with the complied study guide, and stated that the guide has had a positive impact on their scores and learning process. They also declared that by using the study guide, they have become more familiar with their responsibilities and teachers' duties, score distribution, the department and the educational goals of the department, and also with the oral medicine course, and have entered the department with a more open vision and have witnessed their own progress. The students acknowledged these factors as the strength points of the study guide.

\section{Acknowledgements:}

This project has been performed in the format of student thesis no. 4975 during 20132014 at the dental school of Tehran University of Medical Sciences with financial support of the education development center of Tehran University of Medical Sciences.

\section{References:}

1-GennJM, Harden RM. What is medical education here really like? Suggestions for action research studies of climate of medical education environments. Med Teach 1986; 8(2):111-24.

2-Laidlaw JM, Harden RM. What is ... a study guide? Med Teach 1990;12(1):7-12.

3-Babar S,Baig L.Study guide usability survey: Perception of students and teachers of an undergraduate medical college. J Pak Med Assoc 2014;64(10):1114-8.

4-Harden RM, Laidlaw JM, Hesketh EA.AMEE Medical Education Guide No 16: Study guides-their use and preparation.Med Teach 1999;21(3):248-65.

5-HardenRM. What is a spiral curriculum? Med Teach 1999;21(2):141-3.

6-Ross N, Davies D. AMEE guide no. 14: Outcome-based education: Part 4--outcomebased learning and the electronic curriculum at Birmingham Medical School. Med Teach 1999;21(1):26-31.

7-Farhadi S, Jahanbani J, Kakui Nejad M, Bashiri S. The view point of Dentistry Students to achievement of educational objectives: Comparison of Teacher-Oriented and Problem-Based Learning Methods. JAMED 2015;1(1):23-9. 
8-Dent JA, Angell-Preece HM, Ball HM, Ker JS. Using the ambulatory care teaching center to develop opportunities for integrated learning. Med Teach 2001;23(2):171-5.

9-Holsgrove GJ, Lanphear JH, Ledingham I. Study guide: an essential student learning tool in an integrated curriculum. Medical Teacher 1998;20(2):99-103.

10-Mires GJ, Howie PW, Harden RM. A topical approach to planned teaching and learning using a topic- based study guide. Medical Teacher 1998;20(5): 438-41.

11-Roshangar F, Lotfi M, Zamanzadeh V, Abdollahzadeh F, Davoodi A. The Effect of Using Logbook on Nursing Students' Learning. Iran J Med Edu 2010;10(1):64-70. 12-Keyhanmanesh R, Mirzaei Bavil F, Ghojazadeh M, Ebrahimi $H$, Mazouchian $H$, Ebrahimi Saadatlou MA. The Beneficial Effects of Applied Physiology Study Guides on Dentistry Students' Learning. Res Dev Med Edu. 2014;3(2):105-7.

13-Khogali SE, Laidlaw JM, Harden RM. Study guides: a study of different formats. Med Teach 2006;28(4):375-7. 